\title{
8 The Global Economy: Organization, Governance, and Development
}

\author{
Gary Gereffi
}

THE GLOBAL ECONOMY has changed in very significant ways during the past several decades, and these changes are rooted in how the global economy is organized and governed. These transformations affect not only the flows of goods and services across national borders, but also the implications of these processes for how countries move up (or down) in the international system. The development strategies of countries today are affected to an unprecedented degree by how industries are organized, and this is reflected in a shift in theoretical frameworks from those centered around the legacies and actors of nation-states to a greater concern with supranational institutions and transnational organizations. Policymakers, managers, workers, social activists, and many other stakeholders in developed as well as developing nations need a firm understanding of how the contemporary global economy works if they hope to improve their position in it, or forestall an impending decline.

The topic of the global economy is inherently interdisciplinary. No single academic field can encompass it, nor can any afford to ignore it. Because of its vast scope, those pundits who focus on the global economy are likely to be classified as academic interlopers; they run the risk of being too simplistic if they advance forceful hypotheses and too eclectic if they try to capture the full complexity of their topic. Scholars in this field thus have to master what economist Albert Hirschman has popularized as "the art of trespassing” (Hirschman 1981; Foxley, McPherson, and O’Donnell 1986).

The global economy can be studied at different levels of analysis. At the macro level are international organizations and regimes that establish rules and norms for the global community. These include institutions like the World Bank, the International Monetary Fund, the World Trade Organization, and the International Labor Organization, as well as regional integration schemes like the Eu- ropean Union and the North American Free Trade Agreement. These regimes combine both rules and resources, and hence they establish the broadest parameters within which the global economy operates.

At the meso level, the key building blocks for the global economy are countries and firms. Those scholars who take countries as their main analytical unit (as in the varieties-of-capitalism literature) provide an institutional perspective on the main, enduring features of national economies. The global economy is seen as the arena in which countries compete in different product markets. An alternative approach is to focus on firms and interfirm networks as the central units of analysis, and analyze these actors in a global industry or sectoral framework (as in the global commodity chains or industrial districts approaches). These scholars typically take a more organizational approach. In both the institutional and the organizational perspectives on the global economy, we tend to get a top-down focus on leading countries and firms as drivers of change.

Institutionalists like those in the varieties-ofcapitalism school tend to focus on developed or industrialized countries. Alternatively, one can take a development-oriented perspective with regard to countries, and ask how the economic prospects of developing nations are shaped by their position in the global economy. These questions help to bridge the concerns of economic sociologists and development specialists because the theories of industrial upgrading that have emerged in the last couple of decades have been shaped very closely by several of the organizational and institutional theories mentioned above.

At a micro level, there is a growing literature on the resistance to globalization by consumer groups, activists, and transnational social movements (such as those dealing with labor issues and environmental abuses). This research is relevant to a chapter titled "The Global Economy" because 
the very same perspectives used to understand how the global economy is organized are being employed by social and environmental activists to challenge the existing order.

Many theories related to economic sociology incorporate the global economy in their frameworks, but they differ in the degree to which it is conceptualized as a system that shapes the behavior and motivation of actors inside it, or as an arena where nationally determined actors meet, interact, and influence each other (Therborn 2000). This chapter identifies how the global economy has been constructed analytically by a wide range of social scientists. The first task is to define what is really "new" about the global economy in the last half of the twentieth century, which is the main temporal focus of this chapter. The increasingly seamless web of international production and trade networks that girdle the globe appears to be a distinctive feature of the last several decades, and it requires a new kind of organizational perspective that has been growing rapidly. The second section of this chapter takes a closer look at how and why production and trade have been reorganized in the global economy in the contemporary era. Research by a diverse group of scholars from economics, business schools, sociology, and economic geography, among other fields, has contributed to a reconceptualization of the key actors that make up the global economy, and to a realization that the integration of trade and the disintegration of production on a global scale are fundamentally altering our ideas about what connects national economies, firms, places, and people. The third section reviews selected institutional and organization perspectives on the global economy. We will highlight the competing and complementary claims of various approaches, such as the varieties-of-capitalism literature, national business systems, and global commodity chains.

The last two sections of the chapter offer "bottom up" perspectives on the global economy to complement the "top down" views on the reorganization of global industries. The fourth section takes a country perspective, and asks how a focus on global production networks allows us to understand the process of industrial upgrading, whereby economic actors try to move to higher-value activities in the global economy. The fifth and concluding section of the chapter examines several of the emerging challenges and dilemmas for governance and development in the contemporary global economy.

\section{How New Is the Global Economy?}

Much of the globalization debate has been fueled by different conceptions of what is happening "out there" in the global economy, and whether it really represents something new. We need to distinguish the process of internationalization, which involves the mere extension or geographic spread of economic activities across national boundaries, from globalization, which is qualitatively distinct because it involves the functional integration of internationally dispersed activities (Dicken 2003, 12). How functional integration occurs is a topic that we will deal with in more detail below in terms of the governance structures in the global economy. However, one of the key actors that distinguishes the global economy of the latter half of the twentieth century from its predecessors is the transnational corporation (TNC), which we will discuss in this section. ${ }^{1}$

The origins of a global economy can be traced back to the expansion of long-distance trade during the period of 1450-1640, which Wallerstein (1979) has labeled the "long sixteenth century." From the fifteenth century onward, a number of chartered trading companies emerged in Europe, such as the East India Company and the Hudson's Bay Company, which created vast international trading empires. Although their activities were worldwide in scope, their main purpose was trade and exchange, rather than production. The development of a world trading system over a period of several centuries helped to create the tripartite structure of core, semiperipheral, and peripheral economic areas. According to world-systems theory, the upward or downward mobility of nations in the core, semiperiphery, and periphery is determined by a country's mode of incorporation in the capitalist world-economy, and these shifts can only be accurately portrayed by an in-depth analysis of the cycles of capitalist accumulation in the longue durée of history (Wallerstein 1974, 1980, 1989; Arrighi 1994).

The dynamics of the capitalist world-system laid the foundation for a process of industrialization and new international divisions of labor on a global scale. Originally, as defined by the eighteenthcentury political economist Adam Smith ([1776] 1976), the "division of labor" referred simply to the specialization of workers in different parts of the production process, usually in a factory setting. Quite early in the evolution of industrial economies, the division of labor also acquired a geo- 
graphical dimension. Different areas began to specialize in particular types of economic activity. At the global scale, the "classic" international division of labor was between the industrial countries producing manufactured goods, and the nonindustrialized economies that supplied raw materials and agricultural products to the industrial nations and that became a market for basic manufactures. This relatively simple pattern no longer applies. During the decades following the Second World War, trade flows have become far more complex, and so have the relationships between the developed and developing nations of the global economy.

The foundations of the contemporary economic order were established in the late 1940s by the system of financial and trade institutions that were set up at an international conference in Bretton Woods, New Hampshire, in 1944. The principal institutions that constitute the Bretton Woods system are the International Monetary Fund (IMF), the International Bank for Reconstruction and Development (later renamed the World Bank), and the General Agreement on Tariffs and Trade (GATT) (see Held et al. 1999, chaps. 3 and 4). Unlike the classical gold standard system, which collapsed during the First World War, the Bretton Woods financial system required that every currency had a fixed exchange rate vis-à-vis the U.S. dollar, with the dollar's value pegged to gold at $\$ 35$ an ounce. In practice, Bretton Woods became a dollar system because the United States was the leading economy and the only major creditor nation in the first 25 years following the Second World War. While the rise of the Eurocurrency market in the 1960s placed increasing strain on the Bretton Woods financial order, its actual demise came on August 15, 1971, when President Nixon announced that the U.S. dollar was no longer freely convertible into gold, effectively signaling the end of fixed exchange rates.

Notwithstanding these changes, the legacy of the Bretton Woods system remained powerful throughout the latter decades of the twentieth century. The IMF has policed the rules of the international financial order, and intervened in national economies (especially in developing countries) to impose stabilization programs when balance-ofpayments crises were deemed structural rather than cyclical. Following the postwar reconstruction of Europe and Japan, the World Bank increasingly became a development agency for third world nations (Ayres 1983). Its policy recommendations were closely tied to those of the IMF, especially after the neoliberal agenda (dubbed the
Washington Consensus) became established in the 1980s (Gore 2000). GATT, a multilateral forum for trade negotiations, became the primary international trade agency by default when the International Trade Organization, provided by the 1947 Havana Charter, was abandoned by President Truman after it was staunchly opposed in the U.S. Congress. In 1995, the GATT was superseded by the much more powerful World Trade Organization (WTO), which sought to reduce or eliminate a whole range of nontariff barriers and uneven trading conditions between countries.

\section{Distinctive Features of the Contemporary Global Economy, 1960s to the Present}

There is considerable controversy over how to characterize the distinctive aspects of the global economy in the postwar period. Wallerstein $(2000$, 250 ) argues that the period from 1945 to the present corresponds to a typical Kondratieff cycle of the capitalist world-economy, which has an upward and a downward swing: an A-phase of economic expansion from 1945 to $1967-73$, and a B-phase of economic contraction from 1967-73 to the present day. While the evolution of the capitalist world-economy stretches from 1450 to the contemporary era, in world-systems theory it is marked by periods of genesis, normal development, and the current phase of "terminal crisis" (Wallerstein 2000, 2002).

From a trade perspective, the level of economic integration in the latter half of the twentieth century is not historically unprecedented. The decades leading up to 1913 were considered a golden age of international trade and investment. This was ended by the First World War and the Great Depression, when most of the world's economies turned inward. Merchandise trade (imports and exports) as a share of world output did not recover its 1913 level until sometime in the mid-1970s (Krugman 1995, 330-31). ${ }^{2}$ If we take 1960 as the baseline, interconnectedness through trade has vastly increased in recent decades, and furthermore trade has grown consistently faster than output at the world level. Among the $\mathrm{OECD}^{3}$ nations (the 24 richest industrial economies), the ratio of exports to gross domestic product (GDP) roughly doubled from 1960 to 1990 , rising from 9.5 percent to 20.5 percent in this period, and world merchandise trade grew at an average of one and a half times the rate of growth of world GDP from 1965 to 1990 (Wade 1996, 62).

International trade, investment, and finance 
have become the hallmarks of economic globalization. Global interconnectedness through foreign direct investment grew even faster than trade during the 1980s, and the most dynamic multinationalization of all has come in finance and in technology. Flows of foreign direct investment grew three times faster than trade flows and almost four times faster than output between 1983 and 1990 (Wade 1996, 63), and according to one estimate, TNCs control one-third of the world's private sector productive assets (UNCTAD 1993, 1). Globalization appears to have gone furthest in the area of finance. The stock of international bank lending (cross-border lending plus domestic lending, denominated in foreign currency) rose from 4 percent of the GDP of OECD countries in 1980 to an astonishing 44 percent in 1990, and foreign exchange (or currency) trading was 30 times greater than and quite independent of trade flows in the early 1990s (Wade 1996, 64). Global financial flows accelerated in considerable measure because of the growing popularity in the 1980s and 1990s of new financial instruments, such as international bonds, international equities, derivatives trading (futures, options, and swaps), and international money markets (Held et al. 1999, 205-9).

This quantitative assessment of the growth in international trade, investment, and financial flows is one side of the story, but it is challenged by the notion that the nature of global economic integration in the recent era is qualitatively different than in the past. Before 1913, the world economy was characterized by shallow integration manifested largely through trade in goods and services between independent firms and through international movements of portfolio capital. Today, we live in a world in which deep integration, organized primarily by TNCs, is pervasive and involves the production of goods and services in cross-border value-adding activities that redefine the kind of production processes contained within national boundaries (UNCTAD 1993, 113). There is little consensus, however, over what kind of framework to use in analyzing the contemporary global economy because of the breadth and rapidity of change, and the fact that countries, firms, workers, and many other stakeholders in the global economy are affected by these shifts.

A global manufacturing system has emerged in which production and export capabilities are dispersed to an unprecedented number of developing as well as industrialized countries. Fröbel, Heinrichs, and Kreye (1980) likened the surge of manufactured exports from labor-intensive export plat- forms in low-wage economies to a "new international division of labor" that used advanced transport and communication technologies to promote the global segmentation of the production process. The OECD coined the term newly industrializing countries and reflected the concern of advanced capitalist nations that the expanding share of these emergent industrializers in the production and export of manufactured goods was a threat to slumping Western industrial economies (OECD 1979). World-systems theorists argued that the gap between core and periphery in the world economy had been narrowing since the 1950s, and by 1980 the semiperiphery not only caught up with but also overtook the core countries in their degree of industrialization (Arrighi and Drangel 1986, 54-55; Arrighi, Silver, and Brewer 2003).

In retrospect, the assembly-oriented export production in the newly industrializing countries was merely an early stage in the transformation of the global economy into "a highly complex, kaleidoscopic structure involving the fragmentation of many production processes, and their geographical relocation on a global scale in ways which slice through national boundaries" (Dicken 2003, 9). Expanded niches for labor-intensive segments have been created by splitting the production of goods traditionally viewed as skill-, capital-, or technology-intensive and putting the labor-intensive pieces of the value chain in low-wage locations.

In Mexico, for example, the booming exportoriented maquiladora program ${ }^{4}$ has engaged in more sophisticated kinds of manufacturing operations over time. First-generation maquiladoras were labor-intensive with limited technology, and they assembled export products in industries like apparel using imported inputs provided by U.S. clients (Sklair 1993). In the late 1980s and early 1990s, researchers began to call attention to socalled second- and third-generation maquiladoras. Second-generation plants are oriented less toward assembly and more toward manufacturing processes that use automated and semiautomated machines and robots in the automobile, television, and electrical appliance sectors. Third-generation maquiladoras are oriented to research, design, and development, and rely on highly skilled labor such as specialized engineers and technicians. In each of these industries, the maquiladoras have matured from assembly sites based on cheap labor to manufacturing centers whose competitiveness derives from a combination of high productivity, good quality, and wages far below those prevailing north of the border (Shaiken and Herzenberg 1987; 
Carrillo and Hualde 1998; Bair and Gereffi 2001; Cañas and Coronado 2002).

A cover story in the February 3, 2003, issue of Business Week highlighted the impact of global outsourcing over the past several decades on the quality and quantity of jobs in both developed and developing countries (Engardio, Bernstein, and Kripalani 2003). The first wave of outsourcing began in the 1960s and 1970s with the exodus to developing countries of jobs making shoes, clothes, cheap electronics, and toys. After that, simple service work, like processing credit-card receipts and airline reservations in back-office call centers, and writing basic software code, went global. Today, driven by digitization, the Internet, and highspeed data networks that circle the world, all kinds of "knowledge work" that can be done almost anywhere are being outsourced. Global outsourcing reveals many of the key features of contemporary globalization: it deals with international competitiveness in a way that inherently links developed and developing countries; a huge part of the debate centers around jobs, wages, and skills in different parts of the world; and there is a focus on value creation in different parts of the value chain. There are enormous political as well as economic stakes in how global outsourcing evolves in the coming years, particularly in well-endowed and strategically positioned economies like India, China, the Philippines, Mexico, Costa Rica, Russia, parts of eastern Europe, and South Africathat is, countries loaded with college grads who speak Western languages and can handle outsourced information-technology work. India seems particularly well positioned in this area.

However, these shifts reveal a sobering globalization paradox: the dramatic expansion of production capabilities reflected in global outsourcing across a wide range of industries does not necessarily increase levels of development or reduce poverty in the exporting nations. As more and more countries have acquired the ability to make complex as well as standard manufactured goods, barriers to entry have fallen and competitive processes at the production stage of value chains have increased. This has resulted in a pattern that Kaplinsky (2000, 120), following Bhagwati's (1958) original use of the term, has dubbed "immiserizing growth," in which economic activity increases in terms of output and employment, but economic returns fall. The emergence of China and, to a lesser extent, India has expanded the global labor force so significantly that the likely consequence of globalization is to bid down living standards not only for unskilled work and primary products, but increasingly for skilled work and industrial products as well (Kaplinsky 2001, 56). The only way to counteract this process is to search for new sources of dynamic economic rents (i.e., profitability in excess of the competitive norm), which are increasingly found in the intangible parts of the value chain where high-value, knowledgeintensive activities like innovation, design, and marketing prevail (Kaplinsky 2000).

These trends raise fundamental questions about winners and losers in the global economy, and also about the forces and frameworks needed to understand why these changes are occurring, and what their impact is likely to be. In the next section of this chapter, we will review how and why new patterns of international production and trade are emerging. In the subsequent section, we will examine some of the major theoretical perspectives in economic sociology and related fields that seek to account for these institutional and organization features of the global economy.

\section{The Reorganization of Production and Trade IN THE Global Economy}

\section{The Role of Transnational Corporations}

While the postwar international economic order was defined and legitimized by the United States and the other core powers that supported it in terms of the ideology of free trade, it was the way in which TNCs linked the production of goods and services in cross-border, value-adding networks that made the global economy in the last half of the twentieth century qualitatively distinct from what preceded it. Transnational corporations have become the primary movers and shakers of the global economy because they have the power to coordinate and control supply chain operations in more than one country, even if they do not own them (Dicken 2003, 198). Although they first emerged in the late nineteenth and early twentieth centuries in the natural resource (oil, mineral, and agricultural) sectors, TNCs did not play a central role in shaping a new global economic system until after the Second World War.

To the neoclassical economists of the 1950s, the postwar world economy was constituted by international capital flows, which were viewed at the country level as foreign direct investment (FDI). The United States was the main source of outward FDI, and the first empirical studies of U.S. FDI at 
the country level were carried out by Dunning (1958) on the United Kingdom and Safarian (1966) on Canada. Both of these studies were interested in the public policy question of the benefits that U.S. FDI had for a host economy (Rugman 1999), and thus they did not really think about transnational corporations as an institutional actor. The Multinational Enterprise Project at Harvard Business School, which began in 1965 under the direction of Raymond Vernon and lasted for 12 years, tried to remedy the economists' relative neglect of the TNCs. Despite being out of step with its academic brethren in economics departments and business schools, who were using general equilibrium models and rational choice to study the properties of efficient markets, the Harvard Multinational Enterprise Project was distinguished by its emphasis on the strategies and activities of TNCs at the micro level of the firm, rather than as merely one more form of international capital movement (Vernon 1999).

In the 1960s and 1970s, the key players in most international industries were large, vertically integrated TNCs, whose use and abuse of power in the global economy were chronicled by numerous authors (e.g., Sampson 1973; Barnet and Müller 1974). The overseas activities of these firms were primarily oriented toward three main objectives: the search for raw materials; finding new markets for their products; and tapping offshore sources of abundant and relatively low-cost labor (Vernon 1971). ${ }^{5}$ In developing countries, which were attractive to TNCs for all three of these reasons, the predominant model of growth since the 1950s was import-substituting industrialization. This development strategy used the tools of industrial policy, such as local-content requirements, joint ventures, and export-promotion schemes, to induce foreign firms that had established local subsidiaries inside their borders to transfer the capital, technology, and managerial experience needed to set up a host of new industries. In return, TNCs could make and sell their products in the relatively protected domestic markets of Latin America, Asia, and Africa, and even in the socialist bloc connected with the former Soviet Union (see Bergsten, Horst, and Moran 1978; Newfarmer 1985).

By the mid-1980s, several significant shifts were transforming the organization of the global economy. First, the oil shock of the late 1970s and the severe debt crisis that followed it were the death knell for import-substituting industrialization in many developing countries, especially in Latin America. The import-substitution approach had found no way to generate the foreign exchange needed to pay for increasingly costly imports, and escalating debt service payments led to a net outflow of foreign capital that crippled economic growth. ${ }^{6}$ Second, the "East Asian miracle," based on the rapid economic advance of Japan and the so-called East Asian tigers (South Korea, Hong Kong, Taiwan, and Singapore) since the 1960s, highlighted a contrasting development model: export-oriented industrialization. Buttressed by the neoliberal thrust of the Reagan and Thatcher governments in the United States and the United Kingdom, respectively, export-oriented development soon became the prevailing orthodoxy for developing economies around the world. ${ }^{7}$ Third, the transition from import-substituting to exportoriented development strategies during the 1980s in many industrializing countries was complemented by an equally profound reorientation in the strategies of TNCs. The rapid expansion of industrial capabilities and export propensities in a diverse array of newly industrializing economies in Asia and Latin America allowed TNCs to accelerate their own efforts to outsource relatively standardized activities to lower-cost production locations worldwide.

One of the central questions that generated great interest in TNCs was this: To what extent have TNCs supplanted national governments, and in what areas? The attitude of many researchers was that TNCs had the power, the resources, and the global reach to thwart the territorially based objectives of national governments in both developed and developing countries (see Bergsten, Horst, and Moran 1978; Barnet and Müller 1974). This was a key tenet of dependency theory, one of the most popular approaches in the 1970s, which argued that TNCs undercut the ability of nationstates to build domestic industries controlled by locally owned firms (Sunkel 1973; Evans 1979; Gereffi 1983). Even the most balanced scholarly approaches reflected the challenge to national autonomy captured by the title of Raymond Vernon's best-known book, Sovereignty at Bay (1971). The large size of TNCs, whether measured in sales or by more sophisticated calculations of value added, still leads to the conclusion that many TNCs are bigger than countries. ${ }^{8}$ However, the concentrated power of vertically integrated, industrial TNCs has been diminishing for the past couple of decades as a result of the tendency toward both the geographic and the organizational outsourcing of production. Thus, the original concern with how TNCs affect the sovereignty and effec- 
tiveness of national governments needs to be reframed in light of the current shift to a more network-centered global economy, which will be discussed below.

\section{The Emergence of International Trade and Production Networks}

The growth of world trade has probably received the most attention in the globalization literature because of its direct relevance to employment, wages, and the rising number of free trade agreements around the world. The most common causes usually given to explain expanding world trade are technological (improvements in transportation and communication technologies) and political (e.g., the removal of protectionist barriers, such as tariffs, import quotas, and exchange controls, which had restricted world markets from 1913 until the end of the Second World War). ${ }^{9}$ It is also important to acknowledge that the volume of international trade depends to a considerable degree on how boundaries are drawn, both for different geographies of production ${ }^{10}$ and according to whether trade covers final products only or whether it also includes intermediate inputs. However, even though the share of trade in world output surpassed its 1913 peak in the 1980s and 1990s, the sheer volume of trade is probably not sufficient to argue for a qualitative break with the past.

Of far greater significance are several novel features in the nature of international trade that do not have counterparts in previous eras. These suggest the need for a new framework to understand both patterns of competition among international firms and the development prospects of countries that are trying to upgrade their position in diverse global industries. The three new aspects of modern world trade relevant here are (1) the rise of intraindustry and intraproduct trade in intermediate inputs; (2) the ability of producers to "slice up the value chain," in Krugman's (1995) phrase, by breaking a production process into many geographically separated steps; and (3) the emergence of a global production networks framework that highlights how these shifts have altered governance structures and the distribution of gains in the global economy.

\section{Intraindustry Trade in Parts and Components}

Arndt and Kierzkowski (2001) use the term fragmentation to describe the international division of labor that allows producers located in dif- ferent countries and often with different ownership structures to form cross-border production networks for parts and components. Specialized "production blocks" are coordinated through service links, which include activities such as transportation, insurance, telecommunications, quality control, and management specifications. Yeats (2001), analyzing detailed trade data for the machinery and transport equipment group (SITC $7),{ }^{11}$ finds that trade in components made up 30 percent of total OECD exports in SITC 7 in 1995, and that trade in these goods was growing at a faster pace than the overall SITC 7 total. Similarly, Hummels, Rapaport, and Yi (1998, 80-81) argue that the "vertical specialization" of global trade, which occurs when a country uses imported intermediate parts to produce goods it later exports, accounted for about 14.5 percent of all trade among OECD countries in the early 1990s. Vertical specialization captures the idea that countries link sequentially in production networks to produce a final good, although vertical trade itself does not require the vertical integration of firms.

Feenstra (1998) takes this idea one step further, and explicitly connects the "integration of trade" with the "disintegration of production" in the global economy. ${ }^{12}$ The rising integration of world markets through trade has brought with it a disintegration of the production process of multinational firms, ${ }^{13}$ since companies are finding it profitable to outsource (domestically or abroad) an increasing share of their noncore manufacturing and service activities. This represents a breakdown of the vertically integrated mode of productionthe so-called Fordist model, originally exemplified by the automobile industry-on which U.S. industrial prowess had been built for much of the twentieth century (Aglietta 1980). The success of the Japanese model of "lean production" in the global economy since the 1980s, pioneered by Toyota in automobiles, reinforces the central importance of coordinating exceptionally complex interfirm trading networks of parts and components as a new source of competitive advantage in the global economy (Womack, Jones, and Roos 1990; Sturgeon and Florida 2000).

\section{Slicing Up the Value Chain}

The notion of a value-added chain has been a useful tool for international business scholars who have focused on the strategies of both firms and countries in the global economy. Bruce Kogut (1984, 151), a professor at the Wharton School of Business, University of Pennsylvania, was one of 
the first to argue that value chains are a key element in the new framework of competitive analysis that is needed because of the globalization of world markets: "The formulation of strategy can be fruitfully viewed as placing bets on certain markets and on certain links of the value-added chain. . . . The challenge of global strategy formulation is to differentiate between the various kinds of economies, to specify which link and which factor captures the firm's advantage, and to determine where the value-added chain would be broken across borders." In a subsequent paper, Kogut (1985) elaborates the central role of the valueadded chain ${ }^{14}$ in the design of international business strategies, which are based upon the interplay between the comparative advantage of countries and the competitive advantage of firms. While the logic of comparative advantage helps to determine where the value-added chain should be broken across national borders, competitive (or firm-specific) advantage influences the decision on what activities and technologies along the value-added chain a firm should concentrate its resources in. ${ }^{15}$

Michael Porter of Harvard Business School also developed a value-chain framework that he applied both at the level of individual firms (Porter 1985) and as one of the bases for determining the competitive advantage of nations (Porter 1990). At the firm level, a value chain refers to a collection of discrete activities performed to do business, such as the physical creation of a product or service, its delivery and marketing to the buyer, and its support after sale. ${ }^{16}$ On the basis of these discrete activities, firms can establish two main types of competitive advantage: low relative cost (a firm's ability to carry out the activities in its value chain at lower cost than its competitors); or differentiation (performing in a unique way relative to competitors). While competitive advantage is determined at the level of a firm's value chain, Porter argues, "The appropriate unit of analysis in setting international strategy is the industry because the industry is the arena in which competitive advantage is won or lost" $(1987,29)$.

The pattern of competition differs markedly across industries: at one extreme are "multidomestic" industries, in which competition in each country is basically independent of competition in other countries; and at the other end of the spectrum are "global industries," in which a firm's competitive position in one country is significantly impacted by its position in other countries. Since international competition is becoming the norm, Porter believes that firms must adopt "global strategies" in order to decide how to spread the activities in the value chain among countries. ${ }^{17} \mathrm{~A}$ very different set of scholars, studying the political economy of advanced industrial societies, highlighted the transformation from "organized capitalism" to "disorganized" or "competitive" capitalism. This approach is based on dramatic shifts in the strategic and institutional contexts of the global economy in the 1980s toward deregulated national markets and unhampered international exchanges (Offe 1985; Lash and Urry 1987). According to Schmitter (1990, 12), sectors or industries are the key unit for comparative analysis in this setting because they represent a meso level where a number of changes in technology, market structure, and public policy converge.

Our review of the contemporary global economy thus far has highlighted two distinctive shifts: the unparalleled fragmentation and reintegration of global production and trade patterns since the 1970s; and the recognition by Kogut and Porter, among others, ${ }^{18}$ of the power of value-chain or industry analysis as a basis for formulating global strategies that can integrate comparative (locationspecific) advantage and competitive (firm-specific) advantage. However, the third transformation in the global economy that needs to be addressed as a precursor to the global value chain perspective is the remarkable growth of manufactured exports from low-wage to high-wage nations in the past several decades. This phenomenon has produced a range of reactions-from anxiety by producers in developed countries who believe they cannot compete with the flood of low-cost imports, to hope among economies in the South that they can catch up with their neighbors in the North by moving up the ladder of skill-intensive activities, to despair that global inequality and absolute levels of poverty have remained resistant to change despite the rapid progress of a relative handful of developing nations.

\section{Production Networks in the Global Economy}

In the 1990s, a new framework, called global commodity chains (GCC), tied the concept of the value-added chain directly to the global organization of industries (see Gereffi and Korzeniewicz 1994; Gereffi 1999, 2001). This work was based on an insight into the growing importance of global buyers (mainly retailers and brand companies, or "manufacturers without factories") as key drivers in the formation of globally dispersed production and distribution networks. Gereffi (1994a) contrasted these buyer-driven chains to what he termed producer-driven chains. The latter 
are the production systems created by vertically integrated transnational manufacturers, while the former term recognizes the role of global buyers, highlighting the significance of design and marketing in initiating the activities of global production systems. ${ }^{19}$ The GCC approach drew attention to the variety of actors that could exercise power within global production and distribution systems. It was the field-based methodology of GCC research, in particular, that provided new insights into the statistics showing an increase in trade involving components and other intermediate inputs. The trade data alone mask important organizational shifts because they differentiate neither between intrafirm and interfirm trade nor between the various ways in which global outsourcing relationships were being constructed.

A variety of overlapping terms has been used to describe the complex network relationships that make up the global economy. Each of the contending concepts, however, has particular emphases that are important to recognize for a chain analysis of the global economy:

Supply chains. A generic label for an input-output structure of value-adding activities, beginning with raw materials and ending with a finished product

International production networks. A focus on the international production networks in which TNCs act as "global network flagships" (Borrus, Ernst, and Haggard 2000)

Global commodity chains. An emphasis on the internal governance structure of supply chains (especially the producer-driven vs. buyer-driven distinction) and on the role of diverse lead firms in setting up global production and sourcing networks (Gereffi and Korzeniewicz 1994)

French "filière" approach. A loosely knit set of studies that used the filiere (i.e., channel or network) of activities as a method to study primarily agricultural export commodities such as rubber, cotton, coffee, and cocoa (Raikes, Jensen, and Ponte 2000)

Global value chains. Emphasis on the relative value of those economic activities that are required to bring a good or service from conception, through the different phases of production (involving a combination of physical transformation and the input of various producer services), delivery to final consumers, and final disposal after use (Kaplinsky 2000; Gereffi and Kaplinsky 2001)

The "value chain" concept has recently gained popularity as an overarching label for this body of research because it focuses on value creation and value capture across the full range of possible chain activities and end products (goods and services), and because it avoids the limiting connotations of the word commodity, which to some implies the production of undifferentiated goods with low barriers to entry. Like the GCC framework, global value chain (GVC) analysis accepts many of the observations made previously on geographical fragmentation, and it focuses primarily on the issues of industry (re)organization, coordination, governance, and power in the chain (Humphrey and Schmitz 2001). Its concern is to understand the nature and consequences of organizational fragmentation in global industries. The GVC approach offers the possibility of understanding how firms are linked in the global economy, but also acknowledges the broader institutional context of these linkages, including trade policy, regulation, and standards. ${ }^{20}$ More generally, the global production networks paradigm has been used to join scholarly research on globalization with the concerns of both policymakers and social activists, who are trying to harness the potential gains of globalization to the pragmatic concerns of specific countries and social constituencies that feel increasingly marginalized in the international economic arena. ${ }^{21}$

The next section of this chapter looks at different perspectives on governance at the meso level of the global economy, and it will be followed by a discussion of industrial upgrading, which analyzes the trajectories by which countries seek to upgrade their positions in the global economy.

\section{GovernanCe IN THE GLOBAL ECONOMY: INSTITUTIONAL AND ORGANIZATIONAL Perspectives}

Scholars who study the global economy at the meso level form distinct camps in terms of their units of analysis, theoretical orientations, and methodological preferences. The two main units of analysis at the meso level are countries and firms. In the 1970s and 1980s, political economy perspectives dealing with nations and TNCs in the global economy tended to predominate, fueled by dependency theory (Cardoso and Faletto [1969] 1979; Evans 1979), world-systems theory (Wallerstein $1974,1980,1989)$, and statist approaches (Amsden 1989; Wade 1990; Evans 1995), among others. During the last decade, however, research on the global economy has shifted toward institutional and organizational theories. The choice of countries or firms as empirical units has a striking affinity with the researcher's primary theoretical 
TABle 1. Comparison of Varieties of Capitalism and Global Production Networks

\begin{tabular}{|c|c|c|}
\hline Dimension & Varieties of Capitalism & Global Production Networks \\
\hline Theoretical orientation & Institutional analysis & Organizational analysis \\
\hline Unit of analysis & Countries & Interfirm networks \\
\hline Empirical focus & $\begin{array}{l}\text { Advanced industrial economies / } \\
\text { capitalist democracies }\end{array}$ & $\begin{array}{l}\text { Linkages between developed and developing } \\
\text { countries }\end{array}$ \\
\hline $\begin{array}{l}\text { Methodological } \\
\text { preference }\end{array}$ & $\begin{array}{l}\text { Rational actor; } \\
\text { multivariate analysis }\end{array}$ & $\begin{array}{l}\text { Comparative/historical analysis across } \\
\text { industries, firms, and countries }\end{array}$ \\
\hline Research style & $\begin{array}{l}\text { Quantitative, cross-national; } \\
\text { country case studies }\end{array}$ & $\begin{array}{l}\text { International, industry-based field research; } \\
\text { political economy interpretations }\end{array}$ \\
\hline Ideal types & $\begin{array}{l}\text { Liberal and coordinated } \\
\text { market economies }\end{array}$ & $\begin{array}{l}\text { Producer-driven and buyer-driven } \\
\text { commodity chains }\end{array}$ \\
\hline $\begin{array}{l}\text { Main challenges/ } \\
\text { collective action } \\
\text { problems }\end{array}$ & $\begin{array}{l}\text { Coordination problems in } \\
\text { developed countries }\end{array}$ & $\begin{array}{l}\text { Industrial upgrading in developing } \\
\text { countries }\end{array}$ \\
\hline Key concepts & Institutional complementarities & $\begin{array}{l}\text { Lead firms; economic rents; } \\
\text { learning through networks }\end{array}$ \\
\hline
\end{tabular}

orientation: those who study countries tend to adopt institutional perspectives, while those who work with firms favor organizational frameworks. ${ }^{22}$

This paradigm divide at the meso level of the global economy is revealed by looking at two broad literatures, which we label "varieties of capitalism" and "global production networks." The former is closely associated with institutional analysis, and the latter with diverse organizational perspectives. Both approaches tend to focus on governance structures in the global economy, but the scope and content of what is being governed differ greatly. The varieties-of-capitalism literature looks primarily at coordination problems and institutional complementarities in advanced industrial economies, where the nation-state is the explicit unit of analysis. This research is comparative, but not transnational, in orientation. By contrast, the research on global production networks highlights the linkages between developed and developing countries created by TNCs and interfirm networks. Governance in this context is typically exercised by lead firms in global industries, and one of the key challenges addressed is industrial upgrading - that is, how developing countries try to improve their position in the global economy, which is characterized both by power asymmetries and by opportunities for learning through networks. International and industry-based field research is a requisite in the study of global production networks because publicly available and detailed information at the level of firms is gener- ally lacking. The main dimensions of this comparison are outlined in table 1 .

The institutionalist paradigm encompasses several related approaches that deal with the governance of modern capitalist economies, including regulation theory (Aglietta 1980; Boyer 1989), national systems of innovation (Lundvall 1992; Nelson 1993), social systems of production (Campbell, Hollingsworth, and Lindberg 1991; Hollingsworth, Schmitter, and Streeck 1994; Hollingsworth and Boyer 1997), and varieties of capitalism (Berger and Dore 1996; Kitschelt et al. 1999; Hall and Soskice 2001). All of the authors in this field focus on the "institutional foundations of comparative advantage" in the advanced capitalist democracies, with an emphasis on topics like businessgovernment relations, labor markets and collective bargaining, the welfare state, the internationalization of capital, and innovation systems. A key unifying concept is institutional complementarity, which rests on "multilateral reinforcement mechanisms between institutional arrangements: each one, by its existence, permits or facilitates the existence of the others" (Amable 2000, 656). Complementary institutions and other forms of path dependency lead most scholars in the varieties-ofcapitalism genre to argue vociferously against convergence, given their belief that unique and valued institutions will sustain national diversities despite the withering pressures of international competition in an increasingly open global economy. Actually, the paradigm does allow for a limited form 
of convergence in the sense that advanced market economies are organized into three broad types: liberal market economies, which adopt laissezfaire, probusiness policies (United States, United Kingdom, Canada, and Australia); and coordinated market economies, with their corporatist (strong state-Germany and Japan) and welfare state (strong trade unions-Scandinavian and northern European) variants. However, there is no serious effort to extend this paradigm to address the varieties of capitalism in the vast majority of countries that are in the developing world..$^{23}$

The global production networks paradigm provides a very different perspective on the global economy because its organizational lens focuses on transnational linkages between developed and developing nations. The central questions deal with the kinds of governance structures that characterize global industries, how these governance arrangements change, and what consequences these shifts have for development opportunities in rich and poor countries alike. International institutionals, such as trade and intellectual property regimes, clearly shape inclusion and exclusion of countries and firms in global production networks, but this approach tends to focus on the strategies and behavior of the players (firms), while the rules of the game (regulatory institutions) are taken as an exogenous variable.

Notwithstanding the potential complementarities between institutional and organizational perspectives on the global economy, there has been virtually no dialogue between these two literatures. They do not cite one another's research or engage in collaborative projects, despite the fact that both are concerned with the international forces shaping countries and firms in the global economy.

There are several hybrid approaches that seek to bridge this gap between organizational and institutional frameworks. One of these is the business systems perspective, pioneered by Whitley (1992a, 1992b). As defined by Whitley (1996, 412), "Business systems are particular forms of economic organization that have become established and reproduced in certain institutional contexts-local, regional, national or international. They are distinctive ways of coordinating and controlling economic activities which developed interdependently with key institutions which constitute particular kinds of political, financial, labor and cultural systems. The more integrated and mutually reinforcing are such institutional systems over a particular territory or population, the more cohesive and distinctive will be its business system." While firms presumably are central to business systems, Whitley's framework shares the institutionalist paradigm's emphasis on institutional complementarities and cohesion, and national or culturally proximate regions. However, the business systems approach seems relatively ill equipped to deal with the question, How do U.S., European, or Asian business systems respond to globalization? While the business systems logic would lead us to expect that firms of the same nationality maintain their distinctive features in the face of international competition, findings from research on global production networks indicate that the competition among firms from different business systems in overseas markets tends to diminish the influence of national origins on firms' behavior (Gereffi 1996, $433) .^{24}$

Sociologists have looked at a range of other actors in the global economy. "Business groups," defined as a collection of firms bound together in persistent formal or informal ways, are a pervasive phenomenon in Asia, Europe, Latin America, and elsewhere (Granovetter 1994; "Business Groups and Social Organization," this volume). Business groups may encompass kinship networks, but they are not delimited by family boundaries because the goals of families can conflict with the principles of profit maximization that characterize firms in these groups. Business groups play a role in the global economy through their impact on national market structures, and on product variety and product quality in international trade (Feenstra, Yang, and Hamilton 1999). Transnational business networks based on family or ethnic ties are another form of economic organization that shapes global production and trade (Hamilton, Zeile, and Kim 1989; Yeung 2000). Japanese sogo shosha, British trading companies, and Chinese and Indian merchants laid the social groundwork for the long-distance supply routes between Asian producers and their export markets (Gereffi 1999, 60-61). For Castells (1996), the universality of network society in the information age is a defining feature of the modern era. Others argue that the global system is now ruled by a transnational capitalist class, which is more interested in building hegemony than in domination and control (Sklair 2001; Carroll and Fennema 2002).

At a more micro level, phenomena within nation-states can also reflect globalization processes. Meyer (2000) defines modern actors on the global stage as entities with rights and interests that create and consult collective rules, that often enhance their legitimacy by adopting common 
forms, and that exercise agency through moral action. From Meyer's "world society" perspective, the modern world is stateless; it is based on shared rules and models, and made up of strong, culturally constituted actors. Sassen (2000) also detaches sovereignty from the national state. She emphasizes the role of global cities as strategic sites for the production of specialized functions to run and coordinate the global economy, and posits that financial and investment deregulation are driving the geographic location of strategic institutions related to globalization deep inside national territories.

\section{INDUSTRIAL UPGRADING AND GLOBAL Production Networks}

Major changes in global business organization during the last several decades of the twentieth century have had a significant impact on the upgrading possibilities of developing countries. This section will illustrate how the reorganization of international trade and production networks affects the capability of developing countries in different regions of the world to improve their positions in the value chains of diverse industries.

Industrial upgrading refers to the process by which economic actors-nations, firms, and workers-move from low-value to relatively highvalue activities in global production networks. Different mixes of government policies, institutions, corporate strategies, technologies, and worker skills are associated with upgrading success. However, we can think about upgrading in a concrete way as linked to a series of economic roles associated with production and export activities, such as assembly, original equipment manufacturing (OEM), original brand name manufacturing $(\mathrm{OBM})$, and original design manufacturing (ODM) (Gereffi 1994b, 222-24). This sequence of economic roles involves an expanding set of capabilities that developing countries must attain in pursuing an upgrading trajectory in diverse industries. In the remainder of this section, we will look at evidence from several sectors to see how global production networks have facilitated or constrained upgrading in developing nations.

\section{Apparel}

The global apparel industry contains many examples of industrial upgrading by developing countries. ${ }^{25}$ The lead firms in this buyer-driven chain are retailers (giant discount stores like Wal- mart and Target, department stores like J.C. Penney and Marks \& Spencer, specialty retailers like The Limited and Gap), marketers (who control major apparel brands, such as Liz Claiborne, Tommy Hilfiger, Polo/Ralph Lauren, Nike), and brand name manufacturers (e.g., Wrangler, Phillipsvan Heusen). These lead firms all have extensive global sourcing networks, which typically encompass 300 to 500 factories in various regions of the world. Because apparel production is quite labor intensive, manufacturing is typically carried out in countries with very low labor costs.

The main stages for firms in developing countries are first, to be included as a supplier (i.e., exporter) in the global apparel value chain; and then to upgrade from assembly to OEM and OBM export roles within the chain. Because of the MultiFiber Arrangement (MFA) associated with the GATT, which used quotas to regulate import shares for the United States, Canada, and much of Europe, at least 50 to 60 different developing countries have been significant apparel exporters since the 1970s, many just assembling apparel from imported inputs using low-wage labor in local export-processing zones.

The shift from assembly to the OEM export role has been the main upgrading challenge in the apparel value chain. It requires the ability to fill orders from global buyers, which includes making samples, procuring or manufacturing the needed inputs for the garment, meeting international standards in terms of price, quality, and delivery, and assuming responsibility for packing and shipping the finished item. Since fabric supply is the most important input in the apparel chain, virtually all countries that want to develop OEM capabilities need to develop a strong textile industry. The OBM export role is a more advanced stage because it involves assuming the design and marketing responsibilities associated with developing a company's own brands.

East Asian newly industrializing economies (NIEs) of Hong Kong, Taiwan, South Korea, and Singapore, which are generally taken as the archetype for industrial upgrading among developing countries, made a rapid transition from assembly to OEM production in the 1970s. Hong Kong clothing companies were the most successful in making the shift from OEM to OBM production in apparel, and Korean and Taiwanese firms pursued OBM in other consumer goods industries like appliances, sporting goods, and electronics. ${ }^{26}$ After mastering the OEM role, leading apparel export firms in Hong Kong, Taiwan, and South Korea began to 


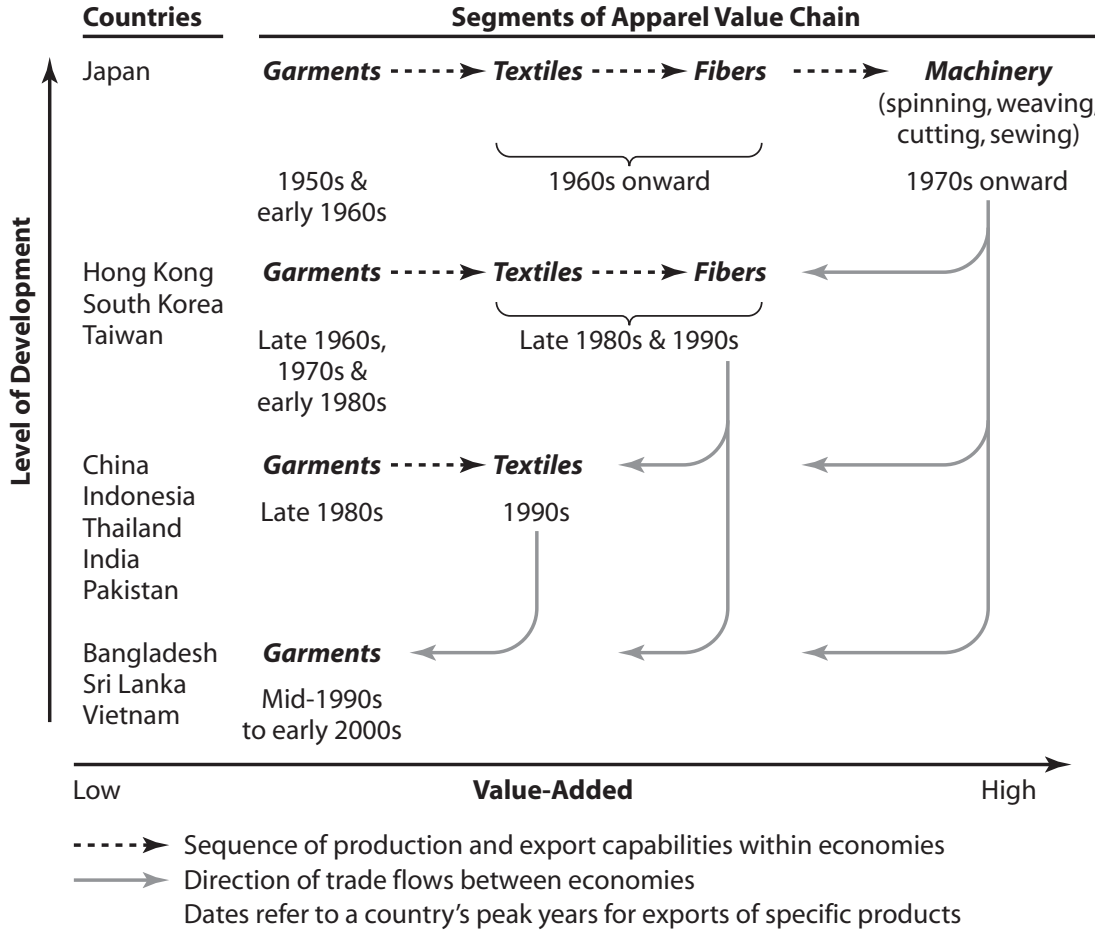

Figure 1. Industrial upgrading in the Asian apparel value chain. Dotted arrows refer to the sequence of production and export capabilities within economies. Solid arrows refer to the direction of trade flows between economies. Dates refer to a country's peak years for exports of specific products. set up their own international production networks in the 1980s, using the mechanism of “triangle manufacturing" whereby orders were received in the East Asian NIEs, apparel production was carried out in lower-wage countries in Asia and elsewhere (using textiles from the NIEs), and the finished product was shipped to the United States or other overseas buyers using the quotas assigned to the exporting nation (Gereffi 1999).

Thus, international production networks facilitated the upgrading of East Asian apparel firms in two ways: first, they were the main source of learning from U.S. and European buyers about how to make the transition from assembly to OEM and OBM; and second, the East Asian NIEs established their own international production networks when faced with rising production costs and quota restrictions at home, and in order to take advantage of lower labor costs and a growing supply base in their region. Asian apparel manufacturers thus made the coordination of the apparel supply chain into one of their own core competences for export success.

Figure 1 presents a stylized model of industrial upgrading in the Asian apparel value chain. The main segments of the apparel chain-garments, textiles, fibers, and machinery-are arranged along the horizontal axis from low to high levels of rela- tive value added in the production process. Countries are grouped on the vertical axis by their relative level of development, with Japan at the top and the least-developed exporters like Bangladesh, Sri Lanka, and Vietnam at the bottom.

Figure 1 reveals several important dynamics about the apparel value chain in Asia, and the GVC approach more generally. First, individual countries progress from low- to high-value-added segments of the chain in a sequential fashion over time. This reinforces the importance in GVC research of looking at the entire constellation of value-added steps in the supply chain (raw materials, components, finished goods, related services, and machinery), rather than just the end product, as traditional industry studies are wont to do. Second, there is a regional division of labor in the apparel value chain, whereby countries at very different levels of development form a multitiered production hierarchy with a variety of export roles (e.g., the United States generates the designs and large orders, Japan provides the sewing machines, the East Asian NIEs supply fabric, and low-wage Asian economies like China, Indonesia, or Vietnam sew the apparel). Industrial upgrading occurs when countries change their roles in these export hierarchies. ${ }^{27}$ Finally, advanced economies like Japan and the East Asian NIEs do not exit the in- 
dustry when the finished products in the chain become mature, as the "product cycle" model (Vernon 1966; 1971, chap. 3) implies, but rather they capitalize on their knowledge of production and distribution networks in the industry and thus move to higher-value-added stages in the apparel chain. This strategic approach to upgrading requires that close attention be paid to competition within and between firms occupying all segments of global value chains.

It is important to note, in closing this section, the key role played by international regulation in the organization of the apparel value chain. The MFA and its apparel quotas will be eliminated in 2005 as a result of the Agreement on Textiles and Clothing in the WTO, and many of the smaller apparel exporters that only do assembly will probably be forced out of the world export market. This should greatly increase export concentration in the global apparel industry, with China likely to be the major winner, along with other large countries such as Mexico, India, Turkey, Romania, and Vietnam that have developed considerable expertise in OEM production. Mexico's rapid move in the 1990s to the top of list as the leading apparel exporter to the United States owes a great deal to the passage of NAFTA in 1994, which allowed the creation of textile production and other backward linkages in Mexico, and thereby facilitated the entry of the U.S. retailers and apparel marketers that previously shunned Mexico in order to import apparel from Asia. In addition, employment in the apparel export industry increased in Mexico from 73,000 in 1994 to nearly 300,000 in 2000 , mainly because Mexico coupled its relatively low wage rates with its recently acquired ability to carry out "full-package" (or OEM) production (Bair and Gereffi 2001; Gereffi, Spener, and Bair 2002). However, China regained the lead from Mexico in 2001 and 2002 , as Mexico has been unable to match the volume and low price of Chinese apparel exports, and because of the intense competition from new suppliers that continue to enter the U.S. market. ${ }^{28}$

\section{Electronics}

Global production networks have been a central feature in the development and upgrading of Asia's large, dynamic electronics sector. In the case of electronics, there have been competing cross-border production networks set up by U.S., Japanese, and European firms, led by TNCs that span the entire value chain in various industries. For high-tech industries like electronics, these producer-driven chains must combine cost competitiveness with product differentiation and speed to market. Cross-border networks not only allow firms to combine these very different market demands effectively, but they also permit the integration of Asia's four distinct development tiers: Japan occupies the first tier; the East Asian NIEs are in the second tier; the major Southeast Asian countries of Malaysia, Thailand, the Philippines, and Indonesia are in the third tier; and the fourth tier contains China and late-late developers such as Vietnam. While the economic crisis of 1997 called East Asia's economic miracle into question, it appears that the structural changes associated with recovery from the crisis will reinforce and increase the opportunities for networked production, as the process of corporate restructuring leads firms to focus on core activities and supplement these with the increasingly specialized technology, skills, and know-how that are located in different parts of Asia (Borrus, Ernst, and Haggard 2000).

The diverse upgrading dynamics in Asian electronics can best be seen by contrasting the U.S. and Japanese production networks. In the mid1990s, U.S. networks were considered to be relatively open and conducive to local development in host countries, while Japanese networks were perceived as closed and hierarchical with activities confined within affiliates that were tightly controlled by the parent company (Borrus 1997). U.S. electronics multinationals typically set up Asian networks based on a complementary division of labor: U.S. firms specialized in "soft" competencies (the definition of standards, designs, and product architecture), and the Taiwanese, Korean, and Singaporean firms specialized in "hard" competencies (the provision of components and basic manufacturing stages). The Asian affiliates of U.S. firms in turn developed extensive subcontracting relationships with local manufacturers, who became increasingly skilled suppliers of components, subassemblies, and even entire electronics systems. Japanese networks, by contrast, were characterized by market segmentation: electronics firms in Japan made high-value, high-end products, while their offshore subsidiaries in Asia continued to make low-value, low-end products. In terms of Asian upgrading, the U.S. production networks were definitely superior: U.S. networks maximized the contributions from their Asian affiliates, and Japanese networks minimized the value added by their regional suppliers. Although there is some evidence that Japanese firms tried to open up their production networks in the late 1990s, at best there has 
been partial convergence, with persistent diversity (Ernst and Ravenhill 2000).

Taiwan's achievements in electronics are especially notable for several reasons. During the 1990s, Taiwan established itself as the world's largest supplier of computer monitors, main boards, mouse devices, keyboards, scanners, and notebook personal computers (PCs), among other items. About 70 percent of the notebook PCs sold under OEM arrangements to American and Japanese computer companies, which resell them under their own logos, have been designed by Taiwanese firms. Acer, Taiwan's leading computer maker, is successful at both OEM and OBM production. Progress has been equally remarkable in the field of electronic components, and Taiwan also boasts one of the world's leading silicon foundry companies, the Taiwan Semiconductor Manufacturing Corporation (Ernst 2000). What is especially impressive about these accomplishments is that small and medium enterprises have played a central role as a source of flexibility in Taiwan's production networks. The role of small and medium enterprises as engines of growth and industrial transformation sets Taiwan apart from South Korea, which has relied extensively on huge, diversified conglomerates (chaebol) as the cornerstone of its electronics sector. The Taiwanese model in the computer industry draws on a combination of several factors: government policies that facilitated market entry and upgrading; strong linkages with large Taiwanese firms and business groups; and organizational innovations, such as the shift from relatively simple, production-based OEM to more complex "turnkey production" arrangements that encompass a wide variety of high-end support services, including design and global supply chain management (Poon 2002).

One of the most striking features of the electronics industry in recent years has been the rise of global contract manufacturers (Sturgeon 2002). A significant share of the world's electronics manufacturing capacity is now contained in a handful of huge contractors, such as Solectron, Flextronics, and Celestica. These firms are pure manufacturers. They sell no products under their own brand names and instead focus on providing global manufacturing services to a diverse set of lead firms, such as Hewlett Packard, Nortel, and Ericsson. All have operations that are truly global in scope, and all have grown dramatically since the early 1990s. Solectron, the largest contractor, expanded from a single Silicon Valley location with 3,500 employees and $\$ 256$ million in revenues in 1988 to a global powerhouse with more than 80,000 employees in 50 locations and nearly $\$ 20$ billion in revenues in 2000. Although they have global reach, all of the largest contract manufacturers are based in North America. Except for the personal computer industry, Asian and European contract manufacturers have not developed, and the few that did were acquired by North American contractors during their buying spree fueled by the inflated stock prices of the 1990s. Global contract manufacturers introduce a high degree of modularity into value chain governance because the large scale and scope of their operations create comprehensive bundles of standardized value chain activities that can be accessed by a variety of lead firms through modular networks.

\section{Fresh Vegetables}

A final example of the role of global production networks in promoting industrial upgrading involves the production of fresh vegetables in Kenya and Zimbabwe for export to U.K. supermarkets. ${ }^{29}$ Africa has very few success stories in the realm of export-oriented development, but some countries of sub-Saharan Africa seem to have found a niche in the fresh vegetables market. Several factors tie this case to our previous examples. First, fresh vegetables are a buyer-driven value chain, albeit in the agricultural sector. As with apparel, there is a high level of concentration at the retail end of the chain. The largest U.K. supermarkets and other food retailers control 70 to 90 percent of fresh produce imports from Africa. These retailers have avoided direct involvement in production; they just specialize in marketing and in the coordination of their supply chains.

Second, a major stimulus for local upgrading in Africa comes from U.K. retailers ratcheting up the standards that exporters must meet. U.K. supermarkets have moved beyond compliance with product quality and legislative (or due diligence) requirements for how produce is grown, processed, and transported. They now are focusing on broader standards that exporters must meet, such as integrated crop management, environmental protection, and human rights. In addition, retailers are beginning to use third-party auditors paid for by producers to ensure compliance with these standards.

Third, more stringent U.K. requirements have led to a decline in the market share of smallholder production and small export firms, which have been excluded from the supermarket supply chain. The horticulture industry in sub-Saharan Africa is 
dominated by a few large exporters that source predominantly from large-scale production units. In both Kenya and Zimbabwe, the top five exporters controlled over three-quarters of all fresh vegetable exports in the late 1990s. ${ }^{30}$

Fourth, as in apparel and electronics, market power in the horticultural chain has shifted from those activities that lower production costs to those that add value in the chain. In fresh vegetables, the latter include investing in postharvest facilities, such as cold storage; barcoding products packed in trays to differentiate varieties, countries, and suppliers; moving into high-value-added items such as ready-prepared vegetables and salads; and treating logistics as a core competence in the chain in order to reduce the time between harvesting, packing, and delivery. Pushing back these functions into Africa can reduce the cost for U.K. supermarkets because adding value to vegetables is labor-intensive and African labor is relatively cheap, but taken together these high-end services can become a new source of competitiveness and an opportunity to add value in Africa.

\section{The Globalization Backlash: Dilemmas of Governance ANd DeVelopment}

In recent decades, a strong antiglobalization movement has emerged. As markets have gone global, many people sense that globalization means greater vulnerability to unfamiliar and unpredictable forces that can bring economic instability and social dislocation, as well as a flattening of culture in the face of well-financed global marketing machines and "brand bullies" (Rodrik 1997; Klein 2000; Ritzer 2000). The so-called Battle of Seattle, the massive protest against WTO trade talks in late 1999, was triggered not only by a lack of accountability and transparency in the deliberations of dominant global economic institutions like the WTO and the IMF, but also by a sense of outrage that corporate-sponsored international liberalization was moving full steam ahead, while the social safety nets and adjustment assistance traditionally provided by national governments were being removed. The historic compromise of "embedded liberalism," characterized by the New Deal in the United States and social democracy in Europe, whereby economic liberalization was rooted in social community, was being undone (Ruggie 2002a).

A major problem is that the purported benefits of globalization are distributed highly unequally. The IMF's managing director, Horst Köhler, has conceded that "the disparities between the world's richest and poorest nations are wider than ever." ${ }^{31}$ Of the world's 6 billion people, almost half $(2.8$ billion) live on less than two dollars a day, and a fifth (1.2 billion) live on less than one dollar a day, with 44 percent of them living in South Asia. In East Asia the number of people living on less than one dollar a day fell from 420 million to 280 million between 1987 and 1998, largely because of improvements in China. Yet the numbers of poor people continue to rise in Latin America, South Asia, and sub-Saharan Africa (World Bank 2001, 3 ). What forces might be able to ameliorate these problems in both governance and development in the global economy?

In the 1990s, there was a sharp escalation in social expectations about the role of corporations in society, both in developed and developing nations (Ruggie 2002b). One reason is that individual companies have made themselves, and in some cases entire industries, targets by engaging in abusive or exploitative behavior. As a result, trust in the corporate sector has been eroded. In addition, there is a growing imbalance in global rule-making: on the one hand, the rules favoring market expansion have become stronger and more enforceable (such as intellectual property rights for software and pharmaceutical companies, or the restrictions on local content provisions and export performance requirements in the WTO); on the other hand, rules that favor other valid social objectives, such as human rights, labor standards, environmental sustainability, or poverty reduction, are lagging behind. These perceived problems and others have provided the fuel for anticorporate campaigns worldwide.

Government policy alone is inadequate to handle these grievances: they are transnational in scope, and they deal with social demands in areas where regulations are weak, ill defined, or simply absent. A variety of new "private governance" responses or certification institutions are emerging (Gereffi, Garcia-Johnson, and Sasser 2001), such as individual corporate codes of conduct; sectoral certification schemes involving nongovernmental organizations (NGOs), firms, labor, and other industry stakeholders; third-party auditing systems, such as SA 8000 for labor standards or the Forest Stewardship Council (FSC) certification for sustainable forestry practices; and the United Nations' Global Compact, an initiative that encourages the private sector to work with the United Nations, in partnership with international labor and civil society organizations, to move toward "good practices" in 
human rights, labor standards, and environmental sustainability in the global public domain. While skeptics claim there is little evidence to show that these codes have significant impact on corporate behavior (Hilowitz 1996; Seidman 2003), proponents generally argue that new systems of certification, enforced either by global consumers or by institutional actors such as the United Nations, can provide the basis for improved regulatory frameworks (Fung, O'Rourke, and Sabel 2001; Williams 2000).

Although there is enormous variation in the character and purpose of different voluntary regulatory schemes-with some schemes created by activists in response to global concerns, and others implemented by corporations as a preemptive effort to ward off activist pressure-certification institutions have gained a foothold in both Europe and North America. In the apparel industry, a variety of certification and monitoring initiatives were established in the latter half of the 1990s.

Clean Clothes Campaign (CCC), a consumer coalition in Europe that aims to improve working conditions in the worldwide garment industry

Social Accountability 8000 (or SA 8000), a code of conduct verification and factory certification program launched in October 1997 by the New York-based Council on Economic Priorities

Fair Labor Association (FLA), which includes major brand merchandisers such as Nike, Reebok, and Liz Claiborne

Worldwide Responsible Apparel Production (WRAP), an industry-initiated certification program designed as an alternative to the FLA and representing the large U.S. apparel manufacturers that produce for the discount retail market

Workers Rights Consortium (WRC), developed by the United Students Against Sweatshops in cooperation with apparel unions, universities, and a number of human rights, religious, and labor NGOs (see Maquila Solidarity Network 2002)

In Mexico, the FLA and WRC collaborated in settling a strike and gaining recognition for the workers' union in the Korean-owned Kukdong factory, which made Nike and Reebok sweatshirts for the lucrative U.S. collegiate apparel market (Gereffi, Garcia-Johnson, and Sasser 2001, 6264). In the coffee sector, the Fair Trade movement has worked with small coffee growers in Costa Rica and elsewhere to get above-market prices for their organic and shade-grown coffees distributed by Starbucks and other specialty retailers (Fitter and Kaplinsky 2001; Ponte 2002).
Private governance in multistakeholder arrangements seeks to strengthen oversight in global supply chains by charting a course that goes beyond conventional top-down regulation based on uniform standards, on the one hand, and reliance on voluntary initiatives taken by corporations in response to social protest, on the other. Some argue that a continuous improvement model based on "ratcheting labor standards" upward would work well in a highly competitive, brand-driven industry such as apparel (Fung, O'Rourke, and Sabel 2001). Others propose a "compliance plus" model that pushes beyond the basic floor of minimum standards set by most codes, and seeks an "inside-out" approach to ethical sourcing based on training and empowerment initiatives that address the needs and interests of factory-based stakeholders (Allen 2002). In either instance, sustainable and meaningful change requires a shift in organizational cultures and expectations regarding improvement of social and environmental conditions.

Governance has become a central theoretical issue in the global economy. Institutional paradigms and local or regional frameworks centered on the nation-state are being superseded by approaches that emphasize transnational governance structures, with an emphasis on power, networks, and the uneven distribution of gains from globalization. Much still needs to be done in this area. The inability of the neoliberal agenda to redress the most serious development problems in the world is leading to fresh thinking on the role of the state and civil society institutions in developing nations (Wolfensohn 1998; IDB 1998, 2000; Garretón et al. 2003). Transnational corporations are being pressured to comply with a broad range of social objectives in multistakeholder institutions of private governance that can have an impact on public policies in the developed as well as the developing world. The challenge in research on the global economy is to create theory and carry out insightful empirical studies that provide tools to understand the constantly changing reality we seek to apprehend and change.

\section{Notes}

I am grateful to Giovanni Arrighi, Fred Block, Frank Dobbin, Mark Granovetter, Evelyne Huber, Larry King, Victor Nee, Gay Seidman, Neil Smelser, and Richard Swedberg for their helpful comments on an earlier draft of this chapter.

1. Another key actor in the contemporary global economy is the state. While the role of the state is an important as- 
pect in many of the institutional perspectives we will review, a more comprehensive discussion of this topic can be found in the chapter "The State and the Economy" by Fred Block and Peter Evans (this volume).

2 . Because the services component of GDP in industrial countries has grown substantially relative to "merchandise" trade like manufacturing, mining, and agriculture, the merchandise component of GDP is shrinking. Thus Feenstra $(1998,33-35)$ uses the ratio of merchandise trade to merchandise value-added to measure the significance of trade for industrial economies between 1890 and 1990. He finds that this ratio doubled for France, Germany, Italy, and Sweden between 1913 and 1990, and nearly tripled for the United States.

3. Organization for Economic Co-operation and Development.

4. The maquiladora program in Mexico, initially called the Border Industrialization Program, was created in 1965 after the United States terminated the bracero program, whose main objective had been to bring in Mexican workers to fulfill the demand for agricultural labor. The end of the bracero program left thousands of unemployed farmworkers in Mexican border cities, and the maquiladora program was set up to alleviate the resultant unemployment and growing poverty. The growth of the maquiladora program has been spectacular, especially in the 1990s. In 1991, Mexico's maquiladora industry generated $\$ 15.8$ billion in exports and employed 466,000 Mexicans; by 2000, it had grown to $\$ 79.5$ billion in exports with nearly 1.3 million employees. Around 15 percent of Mexico's GDP corresponded to maquiladora exports in 2001, and the main destination for these products is the United States (Cañas and Coronado 2002).

5. These three motives for investing abroad subsequently became popularized as distinct forms of foreign direct investment: resource-seeking FDI, market-seeking FDI, and efficiency-seeking FDI (Beviglia Zampetti and Fredriksson 2003, 406).

6. The debt crisis hit all of Latin America very hard. The high external debt burden required the allocation of 25 percent to 30 percent of the region's foreign exchange proceeds merely to cover interest payments, which prompted scholars to refer to the 1980s as Latin America's "lost development decade" (Urquidi 1991).

7. The World Bank's (1993) overview of the East Asian development experience attributes the region's sustained international competitiveness largely to the application of market-friendly policies, including stable macroeconomic man agement, high investments in human capital (especially education), and openness to foreign trade and technology. For a critique of this "Washington consensus" model, see Gore 2000. For a detailed comparison of the import-substituting and export-oriented development strategies in Latin America and East Asia, see Gereffi and Wyman 1990.

8. UNCTAD's World Investment Report, 2002 contains a table of the largest 100 "economies" in the world in 2000 , using a value-added measure for firms that is conceptually comparable to the GDP calculation used for countries. There were 29 TNCs in the top 100 entities on this combined list of countries and nonfinancial companies. The world's largest TNC was ExxonMobil, with an estimated $\$ 63$ billion in value added in 2000; it ranked forty-fifth on the country-company list, making the company approximately equal in size to the economies of Chile or Pakistan (UNCTAD 2002a, 90-91).

9. For OECD countries, falling tariffs were twice as im- portant as falling transport costs in explaining the growth of trade relative to income between 1958 and 1988 (Feenstra 1998, 34).

10. The European Union is a case in point. Taken individually, European Union economies are very open, with an average trade share of 28 percent in 1990, but more than 60 percent of their trade is with each other. Taken as a unit, the European Union's merchandise trade with the rest of the world is only 9 percent of GDP, which is similar to that of the United States (Krugman 1995, 340).

11. SITC refers to Standard International Trade Classification, which is the United Nations' system of trade categories. One-digit product groups, such as SITC 7, are the most general. Components are reported at the level of three-, four-, and five-digit product groups.

12. Feenstra's focus on linkages between the integration of trade and the disintegration of production in the current trade-based era calls to mind a similar duality in Osvaldo Sunkel's classic article "Transnational Capitalism and National Disintegration in Latin America." Writing 25 years before Feenstra in a TNC-based world economy, Sunkel (1973) argued that vertically integrated TNCs were generating international polarization as they used direct foreign investment (rather than trade) to integrate the global economy and simultaneously disintegrate national and regional economies. Thus, we have a curiously reversed image of TNCs moving from being highly integrated to disintegrated actors in the last quarter of the twentieth century, while the economic context shifts from transnational capitalism (based on closed domestic economies) in the 1970s to global value chains (based on specialized economic activities in relatively open economies) in the 1990s.

13. Actually, the disintegration of production through outsourcing of specific activities by large corporations itself leads to more trade, as intermediate inputs cross borders several times during the manufacturing process. This is part of the boundary problem in measuring international trade noted by Krugman (1995).

14. Kogut $(1985,15)$ defines the value-added chain as "the process by which technology is combined with material and labor inputs, and then processed inputs are assembled, marketed, and distributed. A single firm may consist of only one link in this process, or it may be extensively vertically integrated."

15. The main sources of a firm's competitive advantage that can be transferred globally are several economies that exist along and between value-added chains: economies of scale (related to an increase in market size); economies of scope (related to an increase in product lines supporting the fixed costs of logistics, control, or downstream links of the value-added chain); and learning (based on proprietary knowledge or experience). "When these economies exist, industries are global in the sense that firms must compete in world markets in order to survive" (Kogut 1985, 26).

16. A firm's value chain is nested in a larger stream of activities Porter calls a "value system," which include the separate value chains of suppliers, distributors, and retailers (Porter 1990, 40-43).

17. There are two distinct dimensions in how a firm competes internationally: the configuration of a firm's activities worldwide, which range from concentrated (performing an activity, such as research and development, in one location and serving the world from it) to dispersed (performing every activity in each country); and the coordination of value chain activities, which range from tight to loose structures (Porter 1987, 34-38). 
18. Reich (1991) says that core corporations in the United States at the end of the twentieth century have moved from high-volume production of standard commodities to high-value activities that serve the unique needs of particular customers. This requires an organizational shift from vertical coordination (represented as pyramids of power, with strong chief executives presiding over ever-widening layers of managers, atop an even larger group of hourly workers) to horizontal coordination (represented as webs of highvalue activities connected by networks of firms).

19. The GCC approach adopted what Dicken et al. $(2001,93)$ call "a network methodology for understanding the global economy." The objective is "to identify the actors in these networks, their power and capacities, and the ways through which they exercise their power through association with networks of relationships."

20. One of the key findings of value chain studies is that access to developed country markets has become increasingly dependent on participating in global production networks led by firms based in developed countries. Therefore, how value chains function is essential for understanding how firms in developing countries can gain access to globa markets, what the benefits from such access might be, and how these benefits might be increased. A GVC research network has formed to study these issues (see http://www .globalvaluechains.org).

21. Several international organizations have featured the global production networks perspective in recent reports, including UNIDO (2002, chap. 6), UNCTAD (2002a, chap $5 ; 2002$ b, chap. 3$)$, the World Bank $(2003,55-66)$, and the International Labor Organization's program "Global Production and Local Jobs" (see the April 2003 issue of Global Networks for several articles from this project).

22. These distinctions are not ironclad. Often they reflect primary versus secondary research orientations. The scholars who adopt an institutional perspective at the national level can still look at the diversity of firm strategies within national contexts (e.g., Morgan, Kristensen, and Whitley 2001) Similarly, those who use organizational perspectives to understand the evolution of firm strategies and interfirm networks within global industries may ground their generalizations in diverse institutional contexts at the regional, national, and local levels of analysis (e.g., Bair and Gereffi 2001; Gereffi, Spener, and Bair 2002).

23. Guillén (2001) offers a very insightful sociological perspective on the limits of convergence in his systematic comparison of organizational change in Argentina, South Korea, and Spain since 1950. Guillén uses a comparative institutional approach to show that "the emergence of a specific combination of organizational forms in a given country enables it to be successful in the global economy at certain activities but not others" $(2001,16)$.

24. Indeed, companies from the same national business system may show contradictory patterns as they confront global markets. A careful study of seven German transnational companies in three of Germany's core industriesHoechst, Bayer, and BASF in the chemical/pharmaceutical industries; Volkswagen, Mercedes-Benz, and BMW in the automobile industry; and Siemens in electrical/electronic engineering - reveals that strikingly different strategies exist within and between these industries, resulting from a mixture of traditional German ways of doing business and bold global moves (Lane 2001). This departs markedly from Whitley's classification of firms in the German business system as "collaborative hierarchies."

25 . This analysis of industrial upgrading in apparel draws mainly from Gereffi (1999) and Gereffi and Memodovic (2003).

26. However, a number of OBM companies have returned to OEM because it capitalizes on East Asia's core competence in manufacturing expertise. Some East Asian companies pursue a dual strategy of doing OBM for the domestic and other developing country markets, and OEM production for the United States and other industrial country markets.

27. By contrast, the popular "flying geese" model of Asian development assumes that countries industrialize in a clear follow-the-leader pattern (Akamatsu 1961), and no attention is paid to the kind of international production networks that may emerge between the lead economies and their followers.

28. A prime example is sub-Saharan Africa, which, under the African Growth of Opportunity Act of October 2000, has been granted quota-free and duty-free access to the U.S. market for products that meet specified rules of origin (see http://www.agoa.gov).

29. See Dolan and Humphrey 2000 for the facts relevant to this case.

30. The one exception to this high level of concentration is organic produce, for which there is both a price premium and a significant unmet market demand in the United Kingdom because local production is very fragmented. Smaller African exporters still have an opportunity to penetrate this market because organics do not presently require the scale and investment of more exotic forms of produce.

31. "Working for a Better Globalization," remarks by Horst Köhler at the Conference on Humanizing the Global Economy, Washington, D.C., January 28, 2002. Cited in Ruggie 2002a, 3.

\section{REFERENCES}

Aglietta, Michel. 1980. A Theory of Capitalist Regulation. London: New Left Books.

Akamatsu, K. 1961. "A Theory of Unbalanced Growth in the World Economy." Weltwirtschaftliches Archiv 86(1): 196-217.

Allen, Michael. 2002. "Analysis: Increasing Standards in the Supply Chain." Ethical Corporation, October 15.

Amable, Bruno. 2000. "Institutional Complementarity and Diversity of Social Systems of Innovation and Production." Review of International Political Economy 7:645-87.

Amsden, Alice H. 1989. Asia's Next Giant: South Korea and Late Industrialization. Oxford: Oxford University Press.

Arndt, Sven W., and Henryk Kierzkowski, eds. 2001. Fragmentation: New Production Patterns in the World Economy. Oxford: Oxford University Press.

Arrighi, Giovanni. 1994. The Long Twentieth Century. London: Verso.

Arrighi, Giovanni, and Jessica Drangel. 1986. "The Stratification of the World-Economy: An Exploration of the Semiperipheral Zone." Review 10: 9-74.

Arrighi, Giovanni, Beverly J. Silver, and Benjamin D. 
Brewer. 2003. "Industrial Convergence, Globalization, and the Persistence of the North-South Divide." Studies in Comparative International Development 38(1): 3-31.

Ayres, Robert L. 1983. Banking on the Poor: The World Bank and World Poverty. Cambridge: MIT Press.

Bair, Jennifer, and Gary Gereffi. 2001. "Local Clusters in Global Chains: The Causes and Consequences of Export Dynamism in Torreon's Blue Jeans Industry." World Development 29:1885-1903.

Barnet, Richard J., and Ronald E. Müller. 1974. Global Reach: The Power of the Multinational Corporations. New York: Simon and Schuster.

Berger, Suzanne, and Ronald Dore, eds. 1996. National Diversity and Global Capitalism. Ithaca, N.Y.: Cornell University Press.

Bergsten, C. Fred, Thomas Horst, and Theodore H. Moran. 1978. American Multinationals and American Interests. Washington, D.C.: Brookings Institution Press.

Beviglia Zampetti, Americo, and Torbjörn Fredriksson. 2003. "The Development Dimension of Investment Negotiations in the WTO: Challenges and Opportunities." Journal of World Investment 4: 399-450.

Bhagwati, Jaqdish. 1958. "Immiserizing Growth: A Geometrical Note." Review of Economic Studies 25: 201-5.

Borrus, Michael. 1997. "Left for Dead: Asian Production Networks and the Revival of U.S. Electronics." Pp. 139-63 in The China Circle, ed. Barry Naughton. Washington, D.C.: Brookings Institution Press.

Borrus, Michael, Dieter Ernst, and Stephan Haggard, eds. 2000. International Production Networks in Asia. London: Routledge.

Boyer, Robert. 1989. The Regulation School: A Critical Introduction. Trans. Craig Charney. New York: Columbia University Press.

Campbell, John L., J. Rogers Hollingsworth, and Leon N. Lindberg, eds. 1991. Governance of the American Economy. Cambridge: Cambridge University Press.

Cañas, Jesus, and Roberto Coronado. 2002. "Maquiladora Industry: Past, Present, and Future." Business Frontier, issue 2. El Paso Branch of the Federal Reserve Bank of Dallas.

Cardoso, Fernando Henrique, and Enzo Faletto. [1969] 1979. Dependency and Development in Latin America. Trans. Marjory Mattingly Urquidi. Expanded ed. Berkeley and Los Angeles: University of California Press.

Carrillo, Jorge, and Alfredo Hualde. 1998. "Third Generation Maquiladoras: The Delphi-General Motors Case." Journal of Borderlands Studies 13(1): 79-97.

Carroll, William K., and Meindert Fennema. 2002. "Is There a Transnational Business Community?" International Sociology 17(3): 393-419.

Castells, Manuel. 1996. The Rise of the Network Society. Oxford: Blackwell.
Dicken, Peter. 2003. Global Shift: Reshaping the Global Economic Map in the 21st Century. 4th ed. London: Sage.

Dicken, Peter, Philip F. Kelly, Kris Olds, and Henry WaiChung Yeung. 2001. "Chains and Networks, Territories and Scales: Towards a Relational Framework for Analysing the Global Economy." Global Networks 1(2): 89-112.

Dolan, Catherine, and John Humphrey. 2000. "Governance and Trade in Fresh Vegetables: The Impact of UK Supermarkets on the African Horticulture Industry." Journal of Development Studies 37(2): $147-75$.

Dunning, John H. 1958. American Investment in British Manufacturing Industry. London: Allen and Unwin.

Engardio, Peter, Aaron Bernstein, and Manjeet Kripalani. 2003. "Is Your Job Next?" Business Week, February 3, 50-60.

Ernst, Dieter. 2000. "What Permits David to Grow in the Shadow of Goliath? The Taiwanese Model in the Computer Industry." Pp. 110-40 in International Production Networks in Asia, ed. Michael Borrus, Dieter Ernst, and Stephan Haggard. London: Routledge.

Ernst, Dieter, and John Ravenhill. 2000. "Convergence and Diversity: How Globalization Reshapes Asian Production Networks.” Pp. 226-56 in International Production Networks in Asia, ed. Michael Borrus, Dieter Ernst, and Stephan Haggard. London: Routledge.

Evans, Peter B. 1979. Dependent Development: The Alliance of Multinationals, State, and Local Capital in Brazil. Princeton: Princeton University Press.

-. 1995. Embedded Autonomy: States and Industrial Transformation. Princeton: Princeton University Press.

Feenstra, Robert C. 1998. "Integration of Trade and Disintegration of Production in the Global Economy." Journal of Economic Perspectives 12(4): 31-50.

Feenstra, Robert C., Tzu-Han Yang, and Gary G. Hamilton. 1999. "Business Groups and Product Variety in Trade: Evidence from South Korea, Taiwan, and Japan." Journal of International Economics 48(1): 71-100.

Fitter, Robert, and Raphael Kaplinsky. 2001. "Who Gains from Product Rents as the Coffee Market Becomes More Differentiated? A Value-Chain Analysis." IDS Bulletin 32(3): 69-82.

Foxley, Alejandro, Michael S. McPherson, and Guillermo O'Donnell, eds. 1986. Development, Democracy, and the Art of Trespassing: Essays in Honor of Albert O. Hirschman. Notre Dame, Ind.: University of Notre Dame Press.

Fröbel, Folker, Jürgen Heinrichs, and Otto Kreye. 1980. The New International Division of Labor. Cambridge: Cambridge University Press.

Fung, Archon, Dara O'Rourke, and Charles Sabel. 2001. "Realizing Labor Standards: How Trans- 
parency, Competition, and Sanctions Could Improve Working Conditions Worldwide." Boston Review, February-March.

Garretón, Manuel Antonio, Marcelo Cavarozzi, Peter Cleaves, Gary Gereffi, and Jonathan Hartlyn. 2003. Latin America in the Twenty-First Century: Toward a New Sociopolitical Matrix. Miami: North-South Center Press.

Gereffi, Gary. 1983. The Pharmaceutical Industry and Dependency in the Third World. Princeton: Princeton University Press.

1994a. "The Organization of Buyer-Driven Global Commodity Chains: How U.S. Retailers Shape Overseas Production Networks." Pp. 95-122 in Commodity Chains and Global Capitalism, ed. Gary Gereffi and Miguel Korzeniewicz. Westport, Conn.: Praeger.

-. 1994b. "The International Economy and Economic Development." Pp. 206-33 in The Handbook of Economic Sociology, ed. Neil J. Smelser and Richard Swedberg. Princeton: Princeton University Press.

- 1996. "Global Commodity Chains: New Forms of Coordination and Control among Nations and Firms in International Industries." Competition and Change 1(4): 427-39.

- 1999. "International Trade and Industrial Upgrading in the Apparel Commodity Chain." Journal of International Economics 48(1): 37-70.

. 2001. "Shifting Governance Structures in Global Commodity Chains, with Special Reference to the Internet." American Behavioral Scientist 44: 1616-37.

Gereffi, Gary, Ronie Garcia-Johnson, and Erika Sasser. 2001. "The NGO-Industrial Complex." Foreign Policy 125:56-65.

Gereffi, Gary, and Raphael Kaplinsky, eds. 2001. "The Value of Value Chains: Spreading the Gains from Globalisation." Special issue of the IDS Bulletin $32(3)$.

Gereffi, Gary, and Miguel Korzeniewicz, eds. 1994 Commodity Chains and Global Capitalism. Westport, Conn.: Praeger.

Gereffi, Gary, and Olga Memodovic. 2003. "The Global Apparel Value Chain: What Prospects for Upgrading by Developing Countries?" Vienna: UNIDO, Strategic Research and Economy Branch.

Gereffi, Gary, David Spener, and Jennifer Bair, eds. 2002. Free Trade and Uneven Development: The North American Apparel Industry after NAFTA. Philadelphia: Temple University Press.

Gereffi, Gary, and Donald L. Wyman, eds. 1990. Manufacturing Miracles: Paths of Industrialization in Latin America and East Asia. Princeton: Princeton University Press

Gore, Charles. 2000. "The Rise and Fall of the Washington Consensus as a Paradigm for Developing Countries." World Development 28:789-804.

Granovetter, Mark. 1994. "Business Groups." Pp.
453-75 in The Handbook of Economic Sociology, ed. Neil J. Smelser and Richard Swedberg. New York: Russell Sage Foundation; Princeton: Princeton University Press.

Guillén, Mauro F. 2001. The Limits of Convergence: Organization and Organizational Change in Argentina, South Korea, and Spain. Princeton: Princeton University Press.

Hall, Peter A., and David Soskice, eds. 2001. Varieties of Capitalism: The Institutional Foundations of Comparative Advantage. Oxford: Oxford University Press.

Hamilton, Gary G., William Zeile, and Wan-Jin Kim. 1989. "The Network Structure of East Asian Economies." Pp. 105-29 in Capitalism in Contrasting Cultures, ed. Stewart Clegg and Gordon Redding. Berlin: Walter de Gruyter.

Held, David, Anthony McGrew, David Goldblatt, and Jonathan Perraton. 1999. Global Transformations. Stanford, Calif.: Stanford University Press.

Hilowitz, Janet. 1996. Labelling Child Labour Products: A Preliminary Study. Geneva: International Labor Organization.

Hirschman, Albert O. 1981. Essays in Trespassing: Economics to Politics and Beyond. Cambridge: Cambridge University Press.

Hollingsworth, J. Rogers, and Robert Boyer, eds. 1997. Contemporary Capitalism: The Embeddedness of Institutions. Cambridge: Cambridge University Press.

Hollingsworth, J. Rogers, Philippe Schmitter, and Wolfgang Streeck, eds. 1994. Governing Capitalist Economies: Performance and Control of Economic Sectors. Oxford: Oxford University Press.

Hummels, David, Dana Rapaport, and Kei-Mu Yi. 1998. "Vertical Specialization and the Changing Nature of World Trade." Federal Reserve Bank of New York Economic Policy Review, June, 79-99.

Humphrey, John, and Hubert Schmitz. 2001. "Governance in Global Value Chains." IDS Bulletin 32(3): 19-29.

Inter-American Development Bank (IDB). 1998. Facing Up to Inequality in Latin America: Economic and Social Progress in Latin America, 1998-99 Report. Washington, D.C.: IDB.

. 2000. Development beyond Economics: Economic and Social Progress in Latin America, 2000 Report. Washington, D.C.: IDB

Kaplinsky, Raphael. 2000. "Globalisation and Unequalisation: What Can Be Learned from Value Chain Analysis?" Journal of Development Studies 37(2): 117-46. . 2001. "Is Globalization All It Is Cracked Up to Be?" Review of International Political Economy 8(1): 45-65.

Kitschelt, Herbert, Peter Lange, Gary Marks, and John D. Stephens, eds. 1999. Continuity and Change in Contemporary Capitalism. Cambridge: Cambridge University Press.

Klein, Naomi. 2000. No Logo: Taking Aim at the Brand Bullies. New York: Picador. 
Kogut, Bruce. 1984. "Normative Observations on the International Value-Added Chain and Strategic Groups." Journal of International Business Studies, fall, 151-67.

- 1985. "Designing Global Strategies: Comparative and Competitive Value-Added Chains." Sloan Management Review 26(4): 15-28.

Krugman, Paul. 1995. "Growing World Trade." Brookings Papers on Economic Activity 1:327-77.

Lane, Christel. 2001. "The Emergence of German Transnational Companies: A Theoretical Analysis and Empirical Study of the Globalization Process." Pp. 69-96 in The Multinational Firm: Organizing across Institutional and National Divides, ed. Glenn Morgan, Peer Hull Kristensen, and Richard Whitley. Oxford: Oxford University Press.

Lash, Scott, and John Urry. 1987. The End of Organized Capitalism. Oxford: Polity Press.

Lundvall, Bengt-Ake, ed. 1992. National Systems of Innovation: Towards a Theory of Innovation and Interactive Learning. London: Pinter.

Maquila Solidarity Network. 2002. "Memo: Codes Update." No. 12, November.

Meyer, John W. 2000. "Globalization: Sources and Effects on National States and Societies." International Sociology 15(2): 233-48.

Morgan, Glenn, Peer Hull Kristensen, and Richard Whitley, eds. 2001. The Multinational Firm: Organizing across Institutional and National Divides. Oxford: Oxford University Press.

Nelson, Richard R., ed. 1993. National Innovation Systems: A Comparative Analysis. Oxford: Oxford University Press.

Newfarmer, Richard, ed. 1985. Profits, Progress, and Poverty: Case Studies of International Industries in Latin America. Notre Dame, Ind.: University of Notre Dame Press.

Offe, Claus. 1985. Disorganized Capitalism. Ed. John Keane. Cambridge: Polity Press.

Organization for Economic Cooperation and Development (OECD). 1979. The Impact of the Newly Industrializing Countries on Production and Trade in Manufactures. Paris: OECD.

Ponte, Stefano. 2002. "The 'Latte Revolution'? Regulation, Markets, and Consumption in the Global Coffee Chain." World Development 30:1099-1122.

Poon, Teresa Shuk-Ching. 2002. Competition and Cooperation in Taiwan's Information Technology Industry: Inter-firm Networks and Industrial Upgrading. Westport, Conn.: Quorum Books.

Porter, Michael E. 1985. Competitive Advantage. New York: Free Press.

. 1987. "Changing Patterns of International Competition." Pp. 27-57 in The Competitive Challenge: Strategies for Industrial Innovation and Renewal, ed. David J. Teece. Cambridge, Mass.: Ballinger.

- 1990. The Competitive Advantage of Nations. New York: Free Press.
Raikes, Philip, Michael Friis Jensen, and Stefano Ponte. 2000. "Global Commodity Chain Analysis and the French Filière Approach: Comparison and Critique." Economy and Society 29:390-417.

Reich, Robert B. 1991. The Work of Nations: Preparing Ourselves for 21st-Century Capitalism. New York: Alfred A. Knopf.

Ritzer, George. 2000. The McDonaldization of Society. Thousand Oaks, Calif.: Pine Forge Press.

Rodrik, Dani. 1997. Has Globalization Gone Too Far? Washington, D.C.: Institute for International Economics.

Ruggie, John G. 2002a. "Taking Embedded Liberalism Global: The Corporate Connection." Paper presented at the 98th Annual Meeting of the American Political Science Association, Boston, August 26September 1 .

-. 2002b. "The New World of Corporate Responsibility." Financial Times, October 25.

Rugman, Alan M. 1999. "Forty Years of the Theory of the Transnational Corporation." Transnational Corporations 8(2): 51-70.

Safarian, A. Edward. 1966. Foreign Ownership of Canadian Industry. Toronto: McGraw-Hill.

Sampson, Anthony. 1973. The Sovereign State of ITT. New York: Stein and Day.

Sassen, Saskia. 2000. "Territory and Territoriality in the Global Economy." International Sociology 15(2): 372-93.

Schmitter, Philippe C. 1990. "Sectors in Modern Capitalism: Modes of Governance and Variation in Performance." Pp. 3-39 in Labour Relations and Economic Performance, ed. Renato Brunetta and Carlo Dell'Aringa. New York: New York University Press.

Seidman, Gay. 2003. "Monitoring Multinationals: Lessons from the Anti-apartheid Movement." Politics and Society 31(3): 381-406.

Shaiken, Harley, and Stephen Herzenberg. 1987. Automation and Global Production: Automobile Engine Production in Mexico, the United States, and Canada. La Jolla, Calif.: Center for U.S.-Mexican Studies, University of California, San Diego.

Sklair, Leslie. 1993. Assembling for Development: The Maquila Industry in Mexico and the United States. La Jolla, Calif:: Center for U.S.-Mexican Studies, University of California, San Diego.

- 2001. The Transnational Capitalist Class. Oxford: Blackwell.

Smith, Adam. [1776] 1976. An Inquiry into the Nature and Causes of the Wealth of Nations. 2 vols. Oxford: Clarendon Press.

Sturgeon, Timothy. 2002. "Modular Production Networks. A New American Model of Industrial Organization." Industrial and Corporate Change 11(3): 451-96.

Sturgeon, Timothy, and Richard Florida. 2000. "Globalization and Jobs in the Automotive Industry." Final report to the Alfred P. Sloan Foundation. International Motor Vehicle Program, Center for 
Technology, Policy, and Industrial Development, Massachusetts Institute of Technology.

Sunkel, Osvaldo. 1973. "Transnational Capitalism and National Disintegration in Latin America." Social and Economic Studies 22(1): 132-76.

Therborn, Göran. 2000. "Globalizations: Dimensions, Historical Waves, Regional Effects, Normative Governance." International Sociology 15(2): 151-79.

United Nations Conference on Trade and Development (UNCTAD). 1993. World Investment Report: Trans national Corporations and Integrated International Production. New York: United Nations.

. 2002a. World Investment Report: Transnational Corporations and Export Competitiveness. New York: United Nations.

- 2002b. Trade and Development Report, 2002: Developing Countries in World Trade. New York: United Nations.

United Nations Industrial Development Organization (UNIDO). 2002. Industrial Development Report 2002/2003: Competing through Innovation and Learning. Vienna: UNIDO.

Urquidi, Victor L. 1991. "The Prospects for Economic Transformation in Latin America: Opportunities and Resistances," LASA Forum 22(3): 1-9.

Vernon, Raymond. 1966. "International Investment and International Trade in the Product Cycle." Quarterly Journal of Economics 80:190-207.

-. 1971. Sovereignty at Bay: The Multinational Spread of U.S. Enterprises. New York: Basic Books. . 1999. "The Harvard Multinational Enterprise Project in Historical Perspective." Transnational Corporations 8(2): 35-49.

Wade, Robert. 1990. Governing the Market: Economic Theory and the Role of Government in East Asian Industrialization. Princeton: Princeton University Press.

. 1996. "Globalization and Its Limits: Reports of the Death of the National Economy Are Greatly Exaggerated." Pp. 60-88 in National Diversity and Global Capitalism, ed. Suzanne Berger and Ronald Dore. Ithaca, N.Y.: Cornell University Press.

Wallerstein, Immanuel. 1974. The Modern World-System. Vol. 1, Capitalist Agriculture and the Origin of the European World-Economy in the Sixteenth Century. New York: Academic Press. - 1979. The Capitalist World-Economy. Cambridge: Cambridge University Press.
1980. The Modern World-System. Vol. 2, Mercantilism and the Consolidation of the European World-Economy, 1600-1750. New York: Academic Press.

. 1989. The Modern World-System. Vol. 3, The Second Era of Great Expansion of the Capitalist World-Economy, 1730-1840s. New York: Academic Press.

2000. "Globalization or the Age of Transition? A Long-Term View of the Trajectory of the WorldSystem." International Sociology 15(2): 249-65.

. 2002. "The Eagle Has Crash Landed." Foreign Policy 131:60-68.

Whitley, Richard. 1992a. Business Systems in East Asia: Firms, Markets, and Societies. London: Sage. . 1996. "Business Systems and Global Commodity Chains: Competing or Complementary Forms of Economic Organisation?" Competition and Change $1(4): 411-25$.

, ed. 1992b. European Business Systems. London: Sage.

Williams, Oliver F., ed. 2000. Global Codes of Conduct: An Idea Whose Time Has Come. Notre Dame, Ind.: University of Notre Dame Press.

Wolfensohn, James D. 1998. "The Other Crisis." Speech by the president of the World Bank Group to the Board of Governors, October 6. http://www .worldbank.org/html/extdr/am98/jdw-sp/am98-en .htm.

Womack, James P., Daniel T. Jones, and Daniel Roos. 1990. The Machine That Changed the World. New York: Macmillan.

World Bank. 1993. The East Asian Miracle. Oxford: Oxford University Press.

- 2001. World Development Report, 2000/2001: Attacking Poverty. Oxford: Oxford University Press. . 2003. Global Economic Prospects and the Developing Countries, 2003. Washington, D.C.: World Bank.

Yeats, Alexander J. 2001. "Just How Big Is Global Production Sharing?” Pp. 108-43 in Fragmentation: New Production Patterns in the World Economy, ed. S. W. Arndt and H. Kierzkowski. Oxford: Oxford University Press.

Yeung, Henry Wai-chung. 2000. "Economic Globalization, Crisis, and the Emergence of Chinese Business Communities in Southeast Asia." International Sociology 15(2): 266-87. 